\title{
Penerapan Healing Environment Pada Perancangan SeKolah Dasar luar Biasa Bagian Tunalaras
}

\author{
Endhita Januar Bihastuti ${ }^{1^{*}}$, Ummul Mustaqimah ${ }^{2}$, Maya Andria Nirawati ${ }^{3}$ \\ Program Studi Arsitektur, Fakultas Teknik, Universitas Sebelas Maret ${ }^{1}$ \\ Email: endhitajb@gmail.com* \\ Program Studi Arsitektur, Fakultas Teknik, Universitas Sebelas Maret ${ }^{2}$ \\ Program Studi Arsitektur, Fakultas Teknik, Universitas Sebelas Maret ${ }^{3}$
}

\begin{abstract}
Children with emotional and behavioral disorders are one of kind children with special education need. Education as a basic right of every child in Indonesia, especially children with emotional and behaviour disorder, has not been fully realized, this is due to the lack of awareness of parents and teachers. The earlier the children with emotional and behaviour disorders are detected, the higher the expectation to recovery is, so special elementary school for emotional and behaviour disorder facilities are essential. For designing a building that maximizes space program and environmental atmosphere available with the type of needs and program activities that take place, the healing environment is chosen as a design solution at the planned school. Healing environment is related to the creation of an environment that affects health by influencing action and interaction by applying the sensory, natural, and psychological aspects. Aspects of the healing environment will be applied to the spatial, site, form and mass arrangement, and landscape.
\end{abstract}

Keywords: Children with emotional and behaviour disorders,Healing environment,Education facility Special elementary school

\section{PENDAHULUAN}

Anak tunalaras merupakan istilah yang dikenal dalam dunia pendidikan luar biasa untuk anak dengan gangguan emosi dan perilaku. Anak tunalaras dibagi menjadi dua, yaitu anak tunalaras aktif dan anak tunalaras pasif. Anak tunalaras memiliki karakteristik yang kompleks dan seringkali ciri-ciri perilakunya juga dilakukan dilakukan oleh anak-anak sebaya lain. Orangtua dan guru pada umumnya menganggap perilaku tersebut wajar, hanya perlu untuk diberi label nakal dan memperingatkan teman-teman sebayanya untuk berhati-hati bahkan menjauhinya. Pada akhirnya, anak tunalaras mengalami kesulitankesulitan perkembangan yang tidak teridentifikasi, tidak teratasi dan semakin parah, bahkan akan menjadi perilaku menetap hingga mereka dewasa (Aini Mahabbati,2006).

Anak tunalaras cenderung memiliki nilai akademik yang rendah di sekolah reguler, padahal kemampuan intelektual mereka normal. Nilai akademik anak tunalaras yang rendah, disebabkan karena anak tunalaras kurang mampu menyesuaikan diri dengan materi pembelajaran yang diajarkan. Biasanya saat hal tersebut terjadi akan meningkatkan hiper-aktivitas mereka, yaitu karakteristik emosional dan sosial yang menyimpang yang mengganggu jalannya pembelajaran (Aini Mahabbati, 2006). Anak tunalaras yang mengalami gangguan perilaku yang ringan masih dapat bersekolah di sekolah reguler, tetapi anak tunalaras dengan gangguan perilaku yang sedang dan berat membutuhkan layanan khusus yang dikenal dengan Sekolah Luar Biasa Anak Tunalaras (SLB-E) (Aini Mahabbati, 2006).

Di Indonesia, angka partisipasi anak berkebutuhan khusus untuk sekolah masih rendah. Angkanya masih $11 \%$ dari 1,5 juta ABK anak usia sekolah berdasarkan data Badan Pusat Statistik 2015 (Suyatmi, 2016). Jadi, pada dasarnya belum seluruhnya anak tunalaras tertampung dalam pendidikan formal. Penyebab rendahnya angka partisipasi anak tunalaras di SLB-E karena kurangnya informasi dan pengetahuan orang tua tentang tunalaras 
serta stigma buruk masyarakat tentang murid SLB-E.

Indonesia telah meratifikasi Konvensi Hak Anak sejak 5 September 1990. Hal ini merupakan komitmen Indonesia dalam menghormati dan memenuhi hak anak. Pemerintah mentransformasikan hak anak kedalam proses pembangunan dengan mengembangkan kebijakan Kota Layak Anak. Salah satu kota yang mendapat predikat kota layak anak adalah Surakarta, yang telah memulai upaya mewujudkan kota layak anak sejak tahun 2006 (Solo Kota Layak Anak, 2014). Dalam mewujudkan kota layak anak, terdapat seruan internasional tentang penuntansan Education for All yang diharapkan tercapai pada tahun 2015, tetapi pada kenyataannya sampai dengan akhir tahun 2015 belum sepenuhnya dapat tercapai (Suyatmi, 2016).

Populasi anak tunalaras di Surakarta sejumlah 2.738 anak, berdasarkan prevalensi $2 \%$ dari populasi anak sekolah (Sutjihati Somantri, 2006). Dari jumlah tersebut belum semuanya tertampung dan tertangani, karena di Surakarta hanya terdapat dua lembaga pendidikan yang khusus menangani anak tunalaras, yaitu SLBE Bhina Putera Mandiri dan SLBE Prayuwana Anak Indonesia mendapatkan pendidikan formal paling dasar di sekolah dasar. Sebagai pendidikan dasar, siswa sekolah dasar umumnya berusia 7-12 tahun. Anak usia SD tengah belajar untuk mengatur emosinya dalam seting sosial, membalas stimulus perilaku orang lain dengan pengaturan respon dan ekspresi (Aini Mahabbati, 2006). Apabila anak tunalaras yang belum terdeteksi dan tidak dispesifikkan berada di sekolah dasar akan mengakibatkan proses pendidikan cenderung sulit baik bagi guru maupun bagi siswa. Semakin dini terdeteksi dan tertangani, maka kesempatan anak untuk kembali memulihkan perilakunya, sehingga anak dapat melanjutkan pendidikan formal ke jenjang selanjutnya (Sekolah Menengah Pertama) di sekolah reguler.

Manusia dan alam lingkungan pada hakikatnya merupakan satu kesatuan yang tidak dapat dipisahkan. Keduanya saling berinteraksi, dan dari proses interaksi tersebut dapat berupa lingkungan fisik. Dengan demikian manusia membentuk bangunan dan selanjutnya bangunan akan membentuk manusia (Sriti Mayang,2003) Sejalan dengan hal tersebut, faktor lingkungan mempunyai pengaruh yang besar $40 \%$ dalam proses penyembuhan yaitu $40 \%$ faktor fisik, faktor medis $10 \%$, faktor genetis 20\%, dan faktor lain 30\% (Kaplan dkk, 2010 dalam Kurniawati, 2007) Healing environment adalah sebuah sistem dan tempat yang teridiri dari orang-orang, perilaku, perawatan, dan parameter psikologis dan fisik mereka (Wayne B. Jonas, 2007 dalam Phyllis J. Water,2008). Lingkungan fisik merupakan sebuah dimensi dari penyembuahan itu sendiri, ini berkaitan dengan dimensi lain dari sebuah optimal healing environment. Lingkungan dapat berdampak pada kesehatan dengan mempengaruhi perilaku, aksi, dan interaksi dari pasien dan keluarga juga berlaku pada pegawai perawatan

Dalam mendesain dengan pendekatan healing environment, terdapat tiga aspek yaitu, alam, indra, dan psikologis (Murphy, 2008 dalam Vidra Lidyasa dkk, 2012). Aspek alam diaplikasikan pada desain dengan healing garden dan penggunaan elemen serta orientasi bangunan ke alam. Pendekatan indra adalah pendekatan menggunakan elemen-elemen yang dapat memberi stimulus indra manusia yang di aplikasikan dalam desain arsitektural. Indra yang digunakan ada empat, yaitu indra penglihatan (warna, pencahayaan, skala, bentuk), indra pendengaran (musik, kebisingan), indra peraba (tekstur, penghawaan, suhu), dan indra penciuman (bau). Kedua pendekatan tersebut secara tidak langsung mempengaruhi psikologis manusia dengan menghasilkan stimulus yang akan menghasilkan respon

\section{METODE}

Gagasan ide dasar pembuatan objek desain berawal dari fenomena non-arsitektur, yaitu tentang anak tunalaras yang menghasilkan objek desain berupa sekolah dasar luar biasa bagian tunalaras. Kemudian dikembangkan dengan fenomena arsitektur yang ada dengan meakukan alnalisis berupa tinjauan data.

Sekolah dasar luar biasa bagian tunalaras adalah suatu lembaga pendidikan yang memberikan pelayanan pendidikan formal jenjang paling dasar yang secara khusus ditujukan untuk anak tunalaras. Mendesain sekolah khusus anak tunalaras terdapat empat hal yang perlu diperhatikan pada lingkungan 
sekolahnya, yaitu kejelasan fungsi sebuah ruang, ruangan yang dapat mengontrol stimulasi berlebih, penataan ruang yang dapat mempermudah pengawasan, serta sebuah tempat sepi untuk mendukung kebutuhan dari anak tunalaras pasif (Quinn, 2000 dalam Puspita Tunggadewi dkk, 2014).

Untuk memfasilitasi anak tunalaras tersebut, perlu desain bangunan yang dapat memaksimalkan antara program ruang dan suasana lingkungan yang tersedia dengan jenis kebutuhan dan program kegiatan yang berlangsung, maka healing environment dipilih sebagai solusi desain pada sekolah yang direncanakan.

Penerapkan healing environment digunakan sebagai dasar untuk mensintesa antara fenomen arsitektur dan fenomena non arsitektur yang menghasilkan kriteria desain. Kriteria desain menjadi dasar untuk menentukan konsep peruangan, tapak, bentuk dan tata masa bangunan, serta lansekap yang ditransformasikan kan menjadi sebuah desain.

\section{HASIL DAN PEMBAHASAN}

Konsep healing environment adalah membangun suasana melalui penyesuaian semua elemen desain untuk dapat memberikan rangsangan positif bagi indra. Manusia menyesuaikan responnya terhadap rangsang yang datang dari luar, sedangkan stimulus dapat diubah sesuai dengan kebutuhan manusia (Wohlwill, 1974 dalam Sriti Mayang, 2003). Sehingga manusia menyesuaikan respon terhadap lingkungan sekitarnya untuk disesuaikan dengan daya-daya dan kebutuhan yang dimilikinya. Prinsip-prinsip penerapan healing environment pada desain adalah sebagai berikut berikut (Subekti, 2007 dalam Febriani Kurniawati, 2007):

a. Desainnya harus mampu mendukung proses pemulihan baik fisik maupun psikis seseorang.

b. Akses ke alam.

c. Adanya kegiatan-kegiatan outdoor yang berhubungan langsung dengan alam.

d. Desainnya diarahkan pada penciptaan kualitas ruang agar suasana terasa aman, nyaman, dan tidak menimbulkan stres.

Terdapat 3 aspek yang digunakan dalam mendesain healing environment, yaitu indra, alam, dan psikologi (Vidra Lidyasa dkk, 2012).
Setiap aspek memiliki elemen-elemen yang diterapkan di desain seperti pada tabel berikut.

Tabel 1: Penerapan healing environment

\begin{tabular}{|c|c|c|}
\hline Aspek & Elemen & Penerapan \\
\hline \multirow{8}{*}{ Indra } & \multirow[t]{3}{*}{ Penglihatan } & Warna \\
\hline & & Pencahayaan \\
\hline & & Bentuk \\
\hline & \multirow[t]{2}{*}{ Pendengaran } & Musik \\
\hline & & $\begin{array}{l}\text { Pengaturan } \\
\text { kebisingan }\end{array}$ \\
\hline & \multirow[t]{2}{*}{ Peraba } & Tekstur \\
\hline & & Penghawaan \\
\hline & Penciuman & $\mathrm{Bau}$ \\
\hline \multirow{4}{*}{ Alam } & Pemandangan & Lansekap \\
\hline & \multirow[t]{3}{*}{$\begin{array}{l}\text { Healing } \\
\text { garden }\end{array}$} & $\begin{array}{l}\text { Area rekreasi } \\
\text { dan sosial } \\
\text { informal }\end{array}$ \\
\hline & & Area seni \\
\hline & & Area olahraga \\
\hline \multirow{3}{*}{ Psikologis } & \multirow[t]{3}{*}{$\begin{array}{l}\text { Kenyamanan } \\
\text { fisik }\end{array}$} & $\begin{array}{l}\text { Keselamatan } \\
\text { dan } \\
\text { keamanan }\end{array}$ \\
\hline & & Rasa kontrol \\
\hline & & Privasi \\
\hline
\end{tabular}

Anak tunalaras diklasifikasikan menjadi menjadi 2 jenis, yaitu anak tunalaras aktif (externalizing behavior) dan anak tunalaras pasif (internalizing behavior). Prinsip healing environment digunakan dengan menerapkan kontrol dan stimulasi pada lingkungan anak tunalaras. Kontrol dan stimulasi didasarkan pada karakter perilaku mereka yang dibagi menjadi 2, seperti pada tabel di bawah.

Tabel 2: : Analisis penerapan healing environment anak tunalaras tipe externalizing

\begin{tabular}{|c|c|c|}
\hline Karakter & Kontrol & Stimulus \\
\hline $\begin{array}{l}\text { - Suka mengancam } \\
\text { atau } \\
\text { mengintimidasi } \\
\text { - Suka berkelahi } \\
\text { atau menyerang } \\
\text { - Agresif } \\
\text { - Membantah }\end{array}$ & 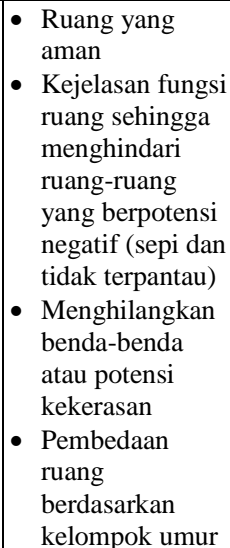 & $\begin{array}{l}\text { Ruang: } \\
\text { - Ruang yang } \\
\text { dapat } \\
\text { mendorong } \\
\text { interaksi } \\
\text { antar siswa } \\
\text { dan guru dan } \\
\text { siswa antar } \\
\text { siswa } \\
\text { - Stimulus } \\
\text { yang } \\
\text { menenangkan } \\
\text { dan kondusif } \\
\text { - Penggunaan } \\
\text { karya seni } \\
\text { yang } \\
\text { menenangkan }\end{array}$ \\
\hline $\begin{array}{l}\text { - } \begin{array}{l}\text { Mengganggu } \\
\text { orang lain }\end{array} \\
\text { - Sulit konsentrasi } \\
\text { - Sulit diam } \\
\text { - Aktif bergerak } \\
\end{array}$ & $\begin{array}{l}\text { - } \text { Pengaturan } \\
\text { perabot yang } \\
\text { memberikan } \\
\text { jarak antar anak }\end{array}$ & $\begin{array}{l}\text { dan memberi } \\
\text { semangat } \\
\text { Kegiatan }\end{array}$ \\
\hline
\end{tabular}




\begin{tabular}{|c|c|c|}
\hline & $\begin{array}{l}\text { - Menyingkirkan } \\
\text { benda yang tidak } \\
\text { dibutuhkan } \\
\text { - Ruang kelas } \\
\text { yang sederhana } \\
\text { - Mengurangi } \\
\text { distraksi atau } \\
\text { pengalih } \\
\text { perhatian } \\
\text { - Ruang } \\
\text { penyimpanan } \\
\text { alat-alat } \\
\text { sebaiknya } \\
\text { tersembunyi } \\
\text { atau sulit } \\
\text { dijangkau anak } \\
\text { - Tidak ada } \\
\text { bidang menonjol } \\
\text { di kelas }\end{array}$ & \multirow[t]{3}{*}{$\begin{array}{l}\text { - Terapi dan } \\
\text { kegiatan } \\
\text { yang sesuai } \\
\text { - Kegiatan } \\
\text { langsung } \\
\text { dengan alam } \\
\text { - Program } \\
\text { terapi yang } \\
\text { beragam } \\
\text { yang dikemas } \\
\text { dengan } \\
\text { permainan } \\
\text { - Kegiatan } \\
\text { yang } \\
\text { terjadwal } \\
\text { - Penerapan } \\
\text { peraturan dan } \\
\text { capaian } \\
\text { - Membantu } \\
\text { siswa } \\
\text { menaati } \\
\text { peraturan }\end{array}$} \\
\hline $\begin{array}{l}\text { Sukaembolos, } \\
\text { suka kabur }\end{array}$ & $\begin{array}{l}\text { Keamanan dan } \\
\text { keselamatan } \\
\text { - Kemudahan } \\
\text { pengawasan } \\
\text { guru atau } \\
\text { pegawai } \\
\end{array}$ & \\
\hline $\begin{array}{ll}\text { - } & \text { Sukar menahan } \\
\text { amarah } \\
\text { - Menolak saran } \\
\text { dan norma }\end{array}$ & $\begin{array}{l}\text { - Terdapat ruang } \\
\text { tenang di setiap } \\
\text { kelas }\end{array}$ & \\
\hline
\end{tabular}

Tabel 3 : Analisis penerapan healingg environment anak tunalaras tipe internalizing

\begin{tabular}{|c|c|c|}
\hline Karakter & Kontrol & Stimulus \\
\hline $\begin{array}{l}\text { - Senang } \\
\text { menyendiri } \\
\text { - Menarik diri } \\
\text { dari } \\
\text { lingkungan }\end{array}$ & $\begin{array}{l}\text { - Menyediakan } \\
\text { ruang untuk } \\
\text { menyendiri } \\
\text { - Mengindari } \\
\text { penempatan } \\
\text { ruang sepi atau } \\
\text { kosong yang } \\
\text { sulit untuk } \\
\text { dipantau atau } \\
\text { diawasi }\end{array}$ & $\begin{array}{l}\text { Ruang menyendiri } \\
\text { yang terkoneksi } \\
\text { dengan ruang-ruang } \\
\text { kegiatan aktif, kantin, } \\
\text { koridor, taman } \\
\text { - Terapi dan kegiatan } \\
\text { yang sesuai } \\
\text { - Kegiatan langsung } \\
\text { dengan alam }\end{array}$ \\
\hline $\begin{array}{l}\text { - Gangguan } \\
\text { tidur }\end{array}$ & $\begin{array}{l}\text { - Terapi dan } \\
\text { konsultasi }\end{array}$ & $\begin{array}{l}\text { - Memberikan } \\
\text { aromaterapi }\end{array}$ \\
\hline $\begin{array}{l}\text { - Kehilangan } \\
\text { minat } \\
\text { - Pandangan } \\
\text { negatif } \\
\text { terhadap } \\
\text { lingkungan, } \\
\text { dirinya, } \\
\text { masa depan } \\
\text { - Lesu } \\
\text { - Kecemasan } \\
\text { dan depresi } \\
\text { - Perasaan } \\
\text { sangat sedih }\end{array}$ & $\begin{array}{l}\text { - Membuat } \\
\text { daftar } \\
\text { pencapaian diri }\end{array}$ & $\begin{array}{l}\text { - Pemberian motivasi } \\
\text { - Membantu siswa } \\
\text { meraih capaian } \\
\text { - Terapi dan kegiatan } \\
\text { yang sesuai } \\
\text { - Kegiatan langsung } \\
\text { dengan alam }\end{array}$ \\
\hline $\begin{array}{l}\text { - Sulit } \\
\text { konsentrasi } \\
\text { - Tidak aktif } \\
\text { - Malu }\end{array}$ & $\begin{array}{l}\text { - Pengaturan } \\
\text { perabot dan } \\
\text { interior }\end{array}$ & $\begin{array}{l}\text { Ruang yang dapat } \\
\text { mendorong interaksi } \\
\text { antar siswa dan guru } \\
\text { dan siswa antar siswa } \\
\text { Program terapi yang } \\
\text { beragam yang } \\
\text { dikemas dengan } \\
\text { permainan }\end{array}$ \\
\hline
\end{tabular}

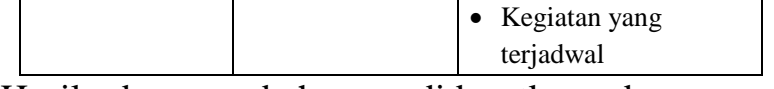

Hasil dan pembahasan didapatkan dengan menerapkan elemen-elemen healing environment yang akan dibahas menjadi empat, yaitu peruangan, tapak, bentuk dan tata massa bangunan, serta lansekap.

\subsection{Peruangan}

Healing environment pada peruangan diterapkan di interior ruang-ruang yang sering digunakan anak tunalaras, yaitu lobby, ruang kelas, ruang tidur, dan ruang belajar.

3.1.1 Ruang kelas

Ruang kelas dibagi menjadi dua berdasarkan karakteristik anak tunalaras, yaitu ruang kelas anak aktif dan ruang kelas anak pasif. Setiap ruang kelas memiliki ruang penyimpanan peralatan sendiri, ini dimaksudkan untuk keamanan dengan menyimpan peralatan belajar yang sedang tidak dipakai dan mengurangi distraksi pandangan dengan meletakkan ruangan pada sisi belakang ruang.

Anak tunalaras memiliki kesulitan mengontrol emosi dan mudah terpicu distraksi yang menyebabkan tantrum, sehingga setiap kelas memiliki ruang tenang. jendela sebagai sumber pencahayaan dan penghawaan alami didesain dengan jendela mati pada bagian bawah sebagai akses pemandangan ke alam dan jendela ayun dibagian atas untuk keamanan sehingga sukar diakses anak-anak.

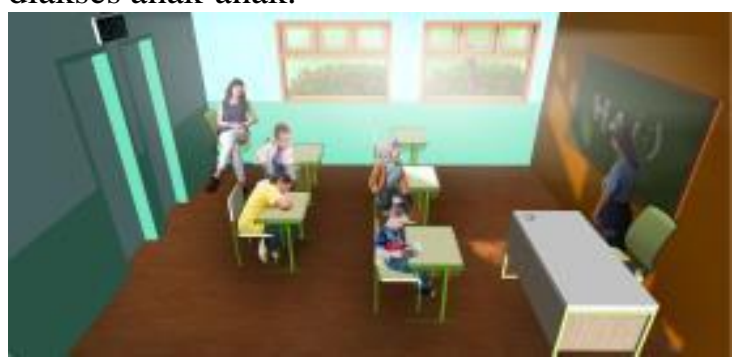

Gambar 1: Ruang kelas anak externalizing

Salah satu karakter anak tunalaras aktif adalah aktif bergerak dan sulit konsentrasi, sehingga bangku siswa diatur zigzag guna memberikan jarak antar siswa dan pandangan siswa ke depan leluasa. Warna yang digunakan untuk ruang kelas anak aktif adalah biru dan oranye. Warna biru degradasi sebagai latar dapat menurunkan perasaan gelisah, tekanan darah, tekanan jantung, dan memberi efek ketenangan untuk anak rewel dan anak yang memiliki masalah perilaku (Kristi S. Gaines dkk, 2011). Sedangkan warna oranye pada area depan mendorong keterbukaan, kemandirian, dan 
menginspirasi komunikasi dan kerjasama (Kristi S. Gaines dkk, 2011).

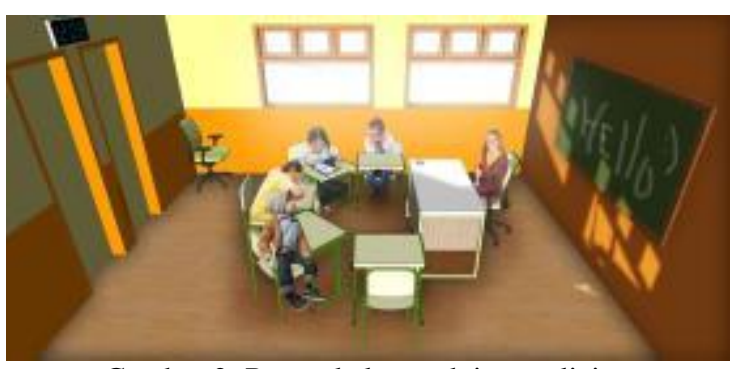

Gambar 2: Ruang kelas anak internalizing

Ruang kelas internalizing menggunakan warna gradasi oranye dan coklat yang memberi efek psikologi kebahagiaan, kenyamanan, kesenangan, rasa intim.

Anak tunalaras pasif memiliki karakter diantaranya tidak aktif, malu, dan sulit konsentrasi, sehingga pola tempat duduk diatur melingkar untuk meningkatkan komunikasi antar siswa dan antara siswa dan guru. Warna yang digunakan pada ruang kelas anak tunalaras pasif adalah gradasi oranye sebagai latar dan warna coklat di depan untuk memberikan efek psikologi kebahagiaan, kenyamanan, kesenangan, dan rasa intim (Kristi S. Gaines dkk, 2011).

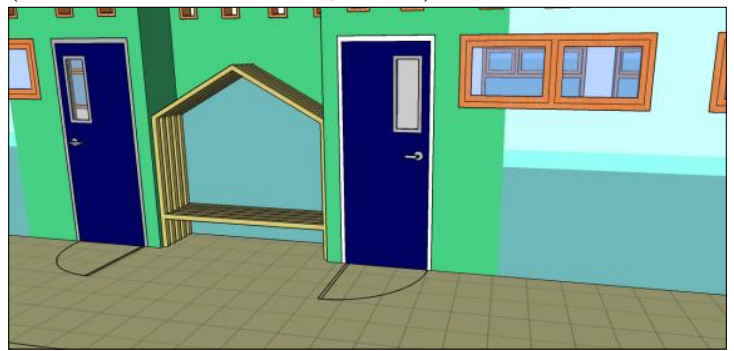

Gambar 7: Ceruk di koridor kelas

Anak tunalaras pasif memiliki karakter suka menyendiri dan menarik diri dari lingkungan, sehingga disediakan ceruk pada koridor agar mereka bisa menyendiri tetapi tetap bisa terpantau dan terkoneksi dengan kegiatan anak aktif.

\subsubsection{Ruang Tidur}

Ruang tidur merupakan ruang yang memiliki privasi tinggi, tetapi juga sebagai ruang untuk menjalin ikatan antara penghuni. Sehingga satu ruang tidur diisi tiga sampai empat anak dengan pengaturan perabot yang memberikan jarak antar area tidur guna menciptakan rasa kontrol sekaligus privasi. Penataan latar kamar mempertimbangkan karakter anak yang ceria dan karakter anak yang mudah terdistraksi, untuk itu dipilih latar gambar alam dengan warna-warna yang memberikan efek tenang dan nyaman seperti warna biru, hijau, merah muda, dan coklat.

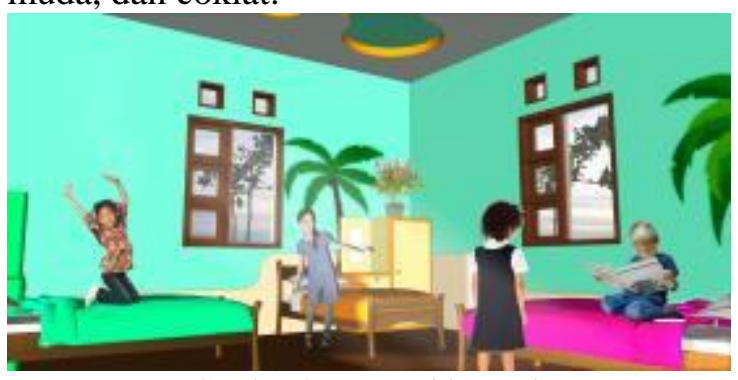

\subsubsection{Ruang belajar}

Gambar 3: Ruang tidur anak

Ruang belajar difungsikan untuk memfasilitasi karakter anak yang berbeda-beda, sehingga pada ruang belajar dibagi menjadi dua area, yaitu area belajar individu dan area belajar kelompok. Area belajar indvidu ditujukan untuk anak yang sulit konsentrasi dan suka menyendiri, sehingga area ini ditata dengan bilik-bilik yang memungkinkan setiap anak memiliki privasi dalam belajar. Area belajar kelompok ditujukan untuk membangun komunikasi antar anak melalui penataan bangku yang melingkar.

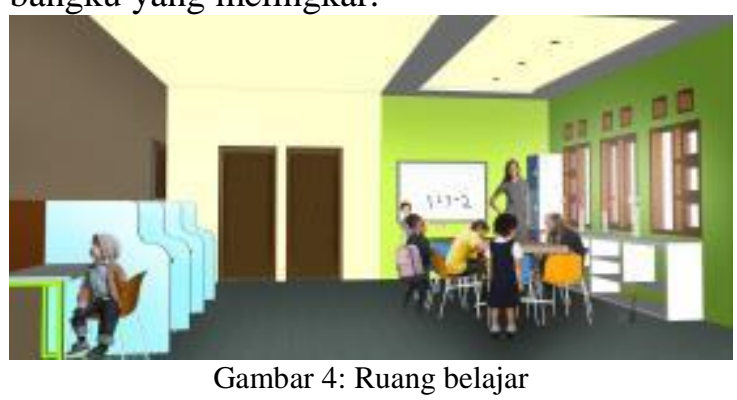

\subsection{Tapak}

Hasil dari tabel 1, 2, dan 3 diterapkan pada tapak berupa pertimbangan dalam pemilihan tapak, mempertimbangkan pencapaian, klimatologi, view dan orientasi, dan kebisingan. Tapak yang dipilih memenuhi kriteria di antaranya berada di dekat pemukiman untuk memudahkan sosialisi dan akses jalur sirkulasi menuju tapak yang tidak ramai untuk keamanan. 


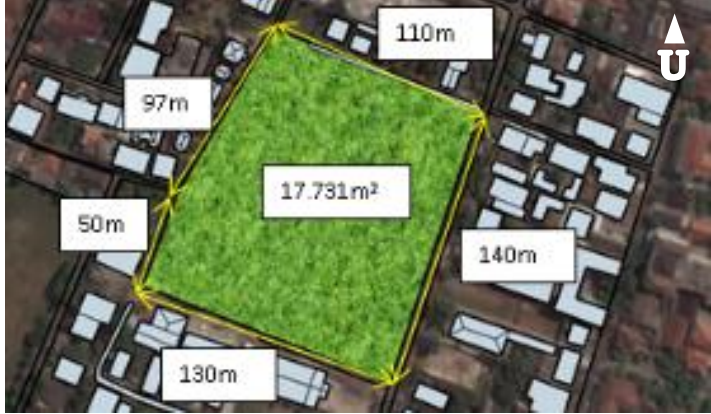

Gambar 5 : Tapak terpilih

Bangunan batas site sebelah utara dan selatan memiliki kepadatan bangunan yang rendah dan vegetasi hijau yang cukup banyak, sehingga view dari site ke arah utara dan selatan sesuai untuk zona kegiatan yang membutuhkan ketenangan seperti zona asrama, zona pendidikan, dan zona penunjang.

Sisi barat site memiliki bangunan perumahan dengan ketinggian satu sampai dua lantai dan jalan pemukiman yang relatif sempit sehingga digunakan sebagai jalur sirkulasi servis. Sisi timur bangunan digunakan sebagai jalur masuk utama karena memiliki kepadatan bangunan yang lumayan, arus yang relatif ramai dan lebar jalan yang paling lebar dari lebar jalan sekitar site lainnya, sehingga jarak pandang dari jalan menuju site baik.

3.3. Bentuk dan Tata massa bangunan

Aspek healing environment berupa psikologis dan indra diterpakan pada bentuk dan tata massa bangunan. Aspek psikologi yang diterapkan ada tiga, yaitu rasa kontrol, keamanan dan keselamatan, serta privasi. Aspek indra yang diterapkan ada yaitu indra penglihatan, indra pendengaran, dan indra peraba.

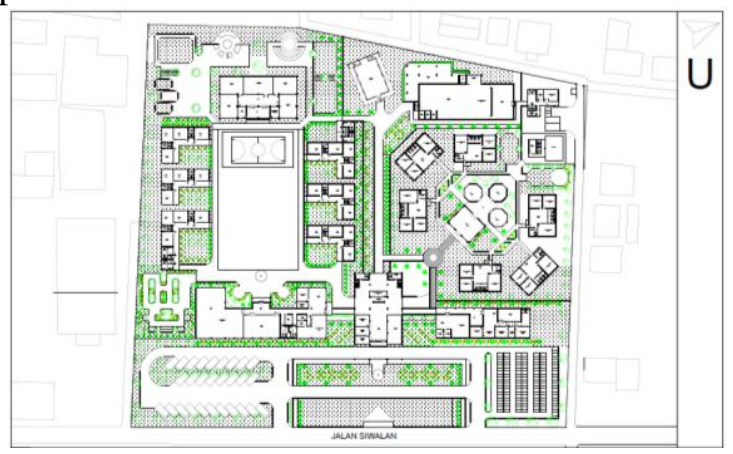

Gambar 6: Denah objek desain

Rasa kontrol diterapkan dengan tiga cara, yang pertama berupa pemilihan bentuk dasar massa berupa persegi yang memiliki sifat sederhana, statis, dan stabil. Kedua penataan massa menggunakan pola klaster terhadap akses masuk ke dalam bangunan, pemisahan ruang kelas berdasarkan jenjang. Ketiga penggunaan warna exterior yang sama untuk bangunan yang memiliki fungsi sama sehingga pengguna mudah mengenali lingkungannya.

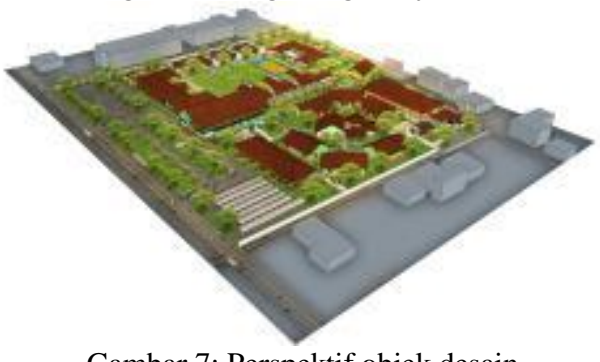

Gambar 7: Perspektif objek desain

Privasi diterapkan dengan penggunaan banyak massa pada asrama dan ruang kelas berdasarkan jenjang umur.

Keamanan dan keselamatan diterapkan dengan peletakan ruang pengelola sekolah di tengah untuk pengawasan, akses masuk satu arah, dan pembatas fisik di setiap zona.

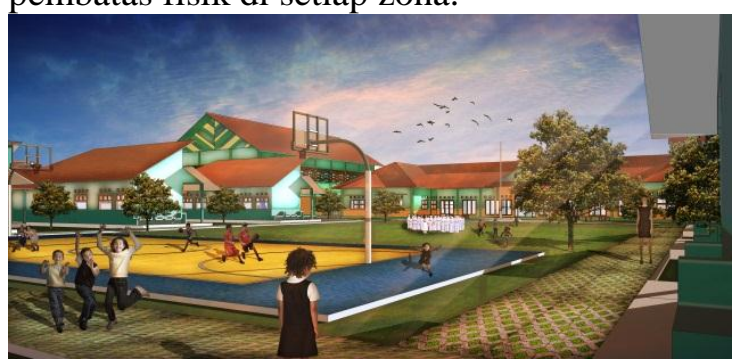

Gambar 8: Warna exterior yang berbeda untuk bangunan dengan fungsi yang berbeda.

Indra penglihatan diterapkan melalui warna, warna yang dipilih untuk exterior bangunan disesuaikan dengan suasana yang dibutuhkan. Indra pendengaran diterapkan melalui musik dan pengaturan kebisingan. Musik dapat memberikan terapi untuk kemampuan motoric, kognitif, berbicara, dan kemampuan motorik dan sosial (Exwan, 2014). Musik diterapkan dengan memasang instalasi audio pada ruang yang membutuhkan, seperti ruang kelas. Pengaturan kebisingan bertujuan untuk mengurangi dampak buruk pada kesehatan, seperti gangguan tidur, kualitas tidur yang buruk, peningkatan tekanan darah, peningkatan denyut jantung dan menurunkan kepuasan pasien.

Indra peraba diterapkan dengan pemilihan tekstur dan penghawaan. Tekstur dapat menjadi batas dan membagi zona yang menciptakan suasana tertentu. Tekstur diterapkan dengan menentukan jenis-jenis tekstur berdasarkan efek pskologis yang dibutuhkan pada setiap 
kebutuhan ruang. Sedangkan penghawaan diterapkan dengan penggunaan penghawaan alami dan buatan sesuai dengan kebutuhan ruang.

\subsection{Lansekap}

Aspek alam pada healing environment yang diterapkan di lansekap adalah healing garden. Tujuan healing garden adalah untuk membuat orang merasa aman, stres berkurang, lebih nyaman, dan merasa segar. Aktivitas luar ruang dapat mendukung proses pembelajaran, mendorong anak untuk memiliki kemajuan berbagai ketrampilan (motorik, sosial emosional, sensorik), dan rekreasi relaksasi. Pengaturan lansekap yang tepat dapat mendorong aktivitas luar ruangan yang optimal, sehingga dibagi menjadi tiga zona, zona area olahraga, zona area rekreasi dan sosial informal, dan zona area seni.

Area olahraga dibagi menjadi dua yaitu area permukaan lunak dan area permukaan keras. Area permukaan lunak diperuntukkan untuk aktivitas berkumpul, lari, dan olahraga lainnya. Area permukaan lunak difungsikan untuk kegiatan olahraga basket.

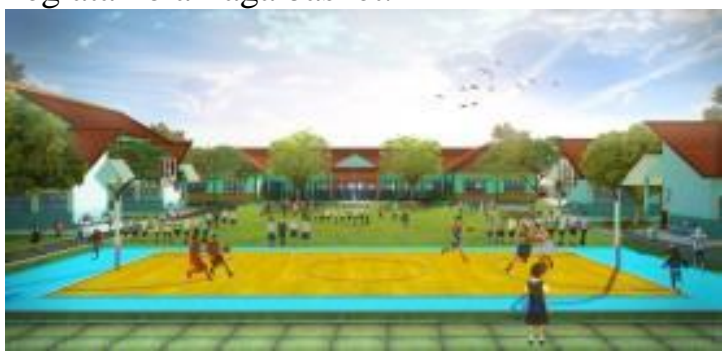

Gambar 9: Area olahraga

Area rekreasi dan sosial informal bertujuan untuk mewadahi aktivitas rekreasi (playground) dan aktivitas sosial antar pengguna. Area rekreasi berisi berbagai pilihan permainan yang memenuhi beberapa kriteria, yaitu aman, berbahan lunak, dan memiliki berbagai alternatif jenis permainan, mengasah motorik anak, dan sesuai dengan umur anak.

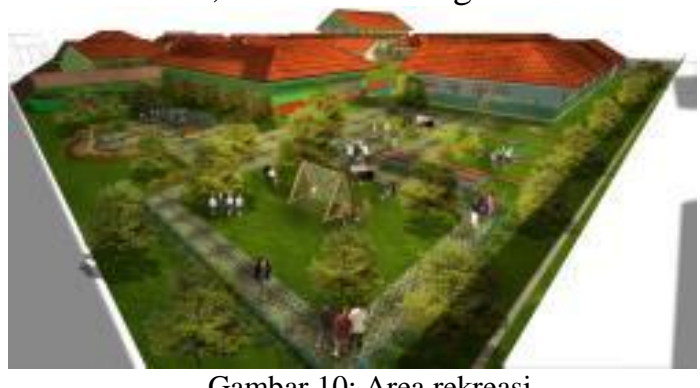

Gambar 10: Area rekreasi
Area sosial informal ditujukan untuk mewadahi kebutuhan sosial dan emosional para pengguna. Area ini juga dapat menjadi pilihan tempat bagi terapi individu maupun kelompok. Pengaturan area sosial yang mempertimbangkan tingkat privasi dapat memberikan rasa kontrol bagi pengguna untuk memiliki pilihan sesuai dengan keadaan yang diinginkan. Area sosial dan informal berupa area duduk, area berkumpul dan area berjalan santai.

Area seni memiliki dampak positif dalam penciptaan healing environment dan bagi anakanak. Area seni ini dibuat untuk mengasah kreatifitas anak, mengasah kemampuan kognitif, sosial emosional, dan motorik. Area seni mewadahi salah satu kegiatan seni yaitu menggambar. Kriteria dalam pembuatan area bermain ini antara lain, aman, mudah dijangkau anak, memiliki tampilan menarik. Area ini juga menjadi sarana salah karakteristik anak tunalaras yaitu suka mencorat-coret.

\section{KESIMPULAN}

Kesimpulan dari penerapan healing environment pada sekolah dasar luar biasa bagian tunalaras di Surakarta adalah sebagai berikut:

a. Prinsip healing environment berupa desainnya harus mampu mendukung proses pemulihan baik fisik maupun psikis seseorang dan desainnya diarahkan pada penciptaan kualitas ruang agar suasana terasa aman, nyaman, dan tidak menimbulkan stres menghasilkan kontrol dan stimulus pada kontrol dan stimulus yang disesuaikan dengan karakter anak tipe externaling dan anak tipe internalizing, selanjutnya diterapkan menggunakan elemen-elemen healing environment pada peruangan, tapak, bentuk dan tata massa bangunan.

b. Prinsip healing environment berupa akses kea lam dan Adanya kegiatan-kegiatan outdoor yang berhubungan langsung dengan alam diterapkan pada objek desain melalui healing garden yang menghasilkan 3 jenis area, yaitu area olahraga, area rekreasi dan sosial informal, dan area seni.

\section{REFERENSI}


Gaines, Kristi S. Curry, Zane D. 2011. "The Inclusive Classroom: The Effect of Color on Learning and Behavior".

Kurniawati, Febriani. 2007. "Peran Healing Environment terhadap Proses Penyembuhan".

Lidyasa, Vidra. Alhamdani, M Ridha. Pebriano, Valentinus. 2012. "Konsep dan Aplikasi Healing Environment dalam Fasilitas Rumah Sakit".

Mahabbati, Aini. 2006. "Identifiasi Anak dengan Gangguan Emosi dan Perilaku di Sekolah Dasar".

Mayang, Sriti. 2003. “ Peran Warna pada Inerior Rumah Sakit berwawasan 'Helaing Environment' terhadap Proses Penyembuhan Pasien". http://puslit.petra.ac.id/journals/interior/. Diakses 4/9/16.

"Solo Kota Layak Anak". 2014. Kampungnesia.

http://kampungnesia.org/berita-solokota-layak-anak-.html. diakses 25/3/16

Somantri, Sutjiati. 2006. "Psikologi Anak Luar Biasa". PT Ravika Aditama

Suyatmi. 2016. "Rakor PKLK Permasalahan dan Tantangan Pendidikan ABK 20152019". Spirit edisi 77.

Tunggadewi, Puspita. Ekasiwi, Sri Nastiti. Setijanti, Purwanita. 2014. "Perancangan Sekolah Luar Biasa Khusus Anak Tunalaras dengan menggunakan Pendekatan Perilaku".

Water, Phyllis J. 2008. "Characteristics of Healing Environment as Describe by Expert Nurses Who Practice within thw Conceptual Framework of Rogers' Science of Unitary Human Being Qualitative Study". 